\title{
Union-Member Relations and Satisfaction with Unions in South \\ Korea
}

\author{
Stephen J. Frenkel \\ Australian Graduate School of Management, University of New South Wales \\ Sarosh Kuruvilla \\ School of Industrial and Labor Relations, Cornell University
}

\begin{abstract}
This paper uses a large sample of South Korean union members working in different industries and occupations to test a model of union satisfaction. The results suggest that union-member relationsmember representation and union leader effectiveness - are more important than the economic results that unions provide to members. These findings are in line with our general argument that, where unions rely on decentralized collective bargaining as the prime method of employment regulation, they depend heavily on internal union relations for their effectiveness. We contend that, if unions are to limit the decline in their influence, assessing and changing internal union relations should be a priority.
\end{abstract}

\section{Introduction}

Over the past decade in particular, trade union power and membership relative to the workforce has been declining in most countries (ILO 1997: 6-21). This has presented unions with what is virtually a survival challenge: to increase their effectiveness. Union effectiveness has several dimensions, including administrative efficiency, bargaining capability and the capacity to organize new members. One direct measure of union effectiveness is member satisfaction with union representation. That this is an important aspect is suggested by findings reported by Jarley et al. (1990), who found that Swedish and US union members' satisfaction with the level of union democracy (or member-union relations) was significantly more important than satisfaction with union performance on bargaining effectiveness in relation to economic issues. The purpose of this paper is to test a similar model in South Korea.

In order to do this, it is necessary to understand the changing context in which South Korean trade unions have found themselves. Two phases can be distinguished. The first phase began in 1987 
with an official announcement of impending democratic reforms. Prior to that year independent trade unions had been suppressed by the state. Massive strikes released the pent-up frustration of workers who had borne the brunt of rapid industrialization under an authoritarian state and uncompromising management. Unions grew rapidly and real wage increases exceeded 10 per cent in 1989 and 1990 (Wilkinson 1994: 341). Long working hours began to decline, facilitated by a legal amendment implemented in 1991. However, proposals to reform labour law failed to gain sufficient parliamentary support. The government continued to crack down on strikers associated with rapidly expanding illegal union groupings, the largest of which was the Korean Confederation of Trade Unions (KCTU) or Minjunochong, which was established in 1994. Union militancy, often combining demands for democratization with improved wages and working conditions, did not encourage compromise by management or the government. Ideological conflict between the government-sanctioned, and more conservative, Federation of Korean Trade Unions and its illegal competitor, the KCTU, discouraged management-labour co-operation.

The second phase began in the early 1990s, when economic growth slowed down. Militancy gave way to a more compromising approach by both management and unions. Unions were (and still are) restricted by law from bargaining above enterprise level. The illegal unions became more defensive and less militant, narrowing their objectives from political goals to wages and working conditions. This gradual replacement of social movement unionism by unionism predicated on stable bargaining relationships brought the government-supported and independent sections of the union movement closer together; nevertheless, the unions continued to compete for members. Meanwhile, employers were restructuring, relocating labour-intensive production to lower-wage countries, and accelerating the introduction of more capital-intensive technology in local plants (Lee 1997:13).

In response to intensifying international competition, employers began to press for more labour flexibility. The government was also looking to reform labour relations. This occurred in 1997 with the introduction of sweeping labour law reforms in the guise of the Trade Union and Industrial Relations Adjustment Act. In exchange for recognition of the KCTU, legal intervention by union federations in disputes and the liberalization of trade union political activity, employers are permitted, under particular conditions, to replace strikers in disputes and are not obliged to pay workers who engage in walk-outs or strikes. In addition, employers are required gradually to cease paying wages to (enterprise) union officials, this practice is to stop completely by the year 2002. With regard to labour flexibility, the 1997 law allows for collective dismissals by way of redundancy subject to prior consultation with the union. Flexible working hours are permitted through collective agreement up to a maximum of 56 hours a week 
without payment of overtime; on a two-weekly or monthly basis. ' Flexible starting and finishing times are also permitted where stipulated by formal company policy (Park 1997: 9).

The 1997-8 financial crisis reinforced tendencies to regulate rather than prohibit union activity and strengthened the motivation for unions to try to alleviate problems caused by company failures and rationalization rather than simply oppose structural change. This approach was partly a response to President Kim Dae Jung's commitment to 'sharing the pain', his promotion of tripartite consultation and the establishment of a $\$ 2.5$ billion unemployment fund. Nevertheless, union members have been suffering major job losses in the aftermath of recession and government policies required by the International Monetary Fund as part of its $\$ 57$ billion bailout package. Unemployment reached 8 per cent in March 1998, and real wages have been declining.

In sum, political and economic changes have induced Korean unions to alter their focus and their strategies. The scope of issues and employer union dynamics have changed: from political and economic matters and negotiation by imposition of sanctions to a narrower concern with economic issues and a greater willingness to negotiate. In losing influence and membership - though this should not be exaggerated - unions are having to assess critically their organizational effectiveness, in particular, relations between officials and members, including mechanisms of representation. It is in this context that the question of members' satisfaction with their union assumes particular importance.

The rationale for our research is that member satisfaction influences their commitment to the union. Union members are likely to defend their union where they see it as a source of satisfaction, and they will tend to promote their interests through their union when they have experienced it as a source of satisfaction. The aim of this paper is to investigate sources of members' satisfaction with unions.

Unions are characterized by two primary sets of relationships: 'internal relations' refer to the relationship between union members and their leaders, while 'external relations' refer mainly to the relationship between the union and employers. Internal relations are meant to aggregate union members' demands through democratic processes resulting in member satisfaction and identification with the union, while external relations are expected to generate improved employment conditions which are also likely to foster member satisfaction and union commitment. The critical question we address is: which of these two relationships is more powerful in influencing member satisfaction?

Our focus is on South Korea, one of the main Asian tiger economies, where the role of unions is changing as workers come to terms with an economic crisis occasioned by high levels of short-term debt, financial speculation and inadequate corporate financial control systems. Using a model that has been successfully employed in other studies (see below), we analyse survey data based on a large 
sample of union members that work in diverse settings. The satisfaction-commitment nexus is elaborated in the first section of the paper, together with a review of the relevant literature on union satisfaction. This highlights the importance of internal union relations as the key source of member satisfaction with their union. The second section summarizes the data and methodology used in this study. In the third section we present our results, interpreting these as supporting the proposition that internal union relations are especially important for members' satisfaction with their unions and hence the perceived effectiveness of Korean unions. This is because relatively informal, decentralized collective bargaining is the main method of employment regulation. In the concluding section we point out some implications for research and union strategy.

\section{Theoretical perspective and relevant literature}

In attempting to serve the interests of their members, unions pursue a variety of goals; however, at more advanced stages of industrialization, developing a web of workplace rules assumes central importance (Flanders 1975: 38-50). Three primary methods have been used for this purpose: (1) controlling the supply of labour; (2) statutory regulation or support by government policy (achieved through control of a political party or through tripartite or bipartite concertation); and (3) collective bargaining. The first avenue is the province of craft unionism, which does not exist in Korea, and the second is unfeasible at the present time on account of the ruling New Korea Party's close identification with employers' demands for more labour market flexibility in the context of increasing foreign direct investment and market deregulation. This leaves the third option - collective bargaining - or what has been described in another context as 'negotiation by imposition' (Price 1980: 76). This refers to largely noninstitutionalized, informal methods of bargaining where, as in the case of Korea in the late 1980s, industrial action was the most popular form of action for securing improved wages and conditions. This was an unstable form that made trade unionism difficult to sustain. Institutionalized collective bargaining, on the other hand, is more favourable. From the union's point of view, this has two contextual and three relational preconditions.

The two contextual factors are: inclusion of relevant workers as union members in the bargaining unit, ,ii and workers' having sufficient power to encourage employers to bargain with unions. The first factor prevents employers' substituting non-union workers for union labour and ensures that union members are not discriminated against, while the second discourages employers from hiring nonunion labour during disputes and encourages employers to negotiate with unions. The three relational 
factors are: support from other unions; commitment to collective endeavour by union members referred to by Hammer and Wazeter (1993: 317) as the members' 'union mentality'; and effective union leadership. This denotes union leaders being responsive to union members, committed to advocating members' short and longer-term interests, and competent to bargain and undertake other political and administrative activities. Taken together, the last two factors point to a positive relationship between union democracy and organizational effectiveness (Strauss 1991: 204-5). Note too that the relationship between member commitment to their union and satisfaction with the union is two-way: more commitment is likely to lead to gains that increase satisfaction, while increased satisfaction is likely to lead to greater commitment (see Gallagher and Strauss 1991: 149).

The link between satisfaction, commitment and behaviour draws on the theory of reasoned action developed by Fishbein and Ajzen (1975), which posits a pattern of causal relations between beliefs, attitudes and intentions. Beliefs about an object (held beliefs or beliefs developed through experience) lead to the formation of an overall attitude towards that object. If the attitude towards that object is favourable, then it leads to the formation of behavioural intentions towards that object, which in turn leads to behaviour. Fishbein and Ajzen argue that direct measures of beliefs will often yield results similar to those of measures of attitudes, since in most studies beliefs and attitudes are assessed by self-reports; this notion is supported by Bem (1972), who suggests the functional equivalence of beliefs and attitude measures. Hence the causal connection between attitudes, behavioural intentions and behaviour.

As applied to unions, there is considerable evidence for the relationship between satisfaction, member commitment and participation. For example, Iversen and Kuruvilla (1996: 574-9) concluded that union satisfaction is causally related to union commitment and behavioural intentions in relation to union activity. In addition, on the basis of US, Canadian and Swedish union members, Sverke and Kuruvilla (1996: 517-27) showed that positive attitudes towards unions tend to result in the development of pro-union behavioural intentions (to participate in union activity, to run for union office, to work on campaigns, etc.) and associated behaviour.

In this research, the condition of bargaining unit inclusion is satisfied by the legal requirement that unions be based on the enterprise for bargaining purposes, and by the convention that all permanent workers join the union (Park and Lee 1995:41). As for the power of labour, the state of the labour market serves as a general proxy.iii Although much less tight now (1998-9) than in previous years, the labour market was still buoyant at the time our data were collected. Thus, the ratio of unfilled vacancies to current employees in 1991 was 5.5. This subsequently declined to 3.0 in 1996 . Real wages 
increased by an estimated annual average of 8.5 per cent over the $1990-6$ period. Union density fell from 21.5 per cent in 1990 to 12.2 per cent in 1996. Meanwhile, industrial disputes remained at low levels although they increased in size. Unions nevertheless continued to influence labour market outcomes, a point underlined by the propagation in early 1997 of the largest general strike in Korea's history. This massive show of force and subsequent strikes resulted in legal changes that provided more restrictions on employer rights to lay off workers (Kim 1997: 34).

Turning to the three relational factors, although conflict between moderate and more radical unions persists, two factors militate against undermining trade union influence. The first is that, at enterprise and workplace level, there is single union representation, so inter-union conflict does not usually affect bargaining and disputes. Second, beginning around mid-1997, the economic recession has brought unions together in their defence of members' rights and in recognition that militancy is less effective in current circumstances.

The other two relational factors are inextricably intertwined and are the unknowns in determining union effectiveness. An instrumental view of unions suggests that reduced economic prospects coupled with a substantial fall in union density indicate union failure to protect members' interests, thereby leading to a decline in member satisfaction and commitment. On the other hand, limited satisfaction and commitment may be primarily the result of union members' perceptions of inadequate communication and hence limited rank-and-file understanding and influence, which is mainly a product of union structures and processes, including the competencies of leaders and members. Regarding the quality of union leadership, although the ratio of union officials to rank-and-file members is relatively high compared with Japan and Europe, Korean union leaders tend to be young and inexperienced, and subject to high turnover (Wilkinson 1994:353). This suggests that they may lack competence in communicating, interpreting and shaping rank-and-file opinion (see Batstone et al. 1977: ch. 3).

Is the level of member satisfaction as indicated by the relative decline of the FKTU and subsequent stasis of the independent union movement (represented by the KCTU) primarily the product of external relations over which unions have less influence, or a consequence of intimal relations? Based mainly on relatively informal, decentralized collective bargaining in Korea, we hypothesize that union effectiveness is likely to be especially dependent on members' satisfaction with internal union relations: on processes of communication and representation, as well as union leadership. 


\section{Relevant Literature}

Several studies have shown that member-union relations (the degree to which union members are satisfied with internal union democracy) is an important determinant of members' satisfaction with their union (Glick et al. 1977:147; Jarley et al. 1990:131-2; Leight 1989). Based on an American sample, Fiorito et al. (1988:298-9) used a facet discrepancy model of union satisfaction to examine the determinants of member satisfaction with union representation. This approach views members' overall satisfaction with the union as the weighted sum of discrepancies between members' expectations and perceived union performance on relevant outcomes of the representation role. In other words, the difference between a member's expectations about union performance in winning wage increases and that member's evaluation of actual union performance constitutes the member's satisfaction or dissatisfaction with the union in terms of that facet of representation, i.e. winning wage increases. Fiorito et al. evaluate several different facets of union representation, and sum up the discrepancies between expectancies and performance to derive the overall members' satisfaction with the union. They also found that, along with union performance on economic issues (such as wages, benefits and job security), member-union relations (the degree to which the union member was satisfied with internal union relations) was an important determinant of overall union satisfaction (Fiorito et al. 1988: 299-302).

In a subsequent study of Swedish and American union members, Jarley et al. (1990:128-9) used a different method to assess members' satisfaction with their union. Respondents were asked several different questions about how satisfied the member was with union performance on various facets, such as winning wages and benefits, improving the quality of work life, and member-union relations (satisfaction with internal union communication, the rank-and-file's influence on union policy and implementation, and grievance handling); these reported satisfaction questions were then used to predict overall union satisfaction. This method has two advantages compared with the method used by Fiorito et al. First, it provides a more direct means of establishing differences in satisfaction on various aspects of union performance, since respondents provide their own assessment of the gap between expectations and perceived union performance for each facet of union activity. Second, regressing overall union satisfaction on these different satisfaction facets makes it possible to obtain estimates of the relative weights that respondents placed on various facets of representation in determining their overall or general satisfaction with the union. As noted earlier, in both the Swedish and American 
samples, Jarley et al. found that satisfaction with member-union relations was the most important determinant of overall satisfaction, exceeding that of union performance on wages and benefits.

The results of these and other studies referred to above support the hypothesis advanced earlier and suggest that union members strongly value internal union relations or the processes of local representation. Although in different contexts, the common feature is reliance on collective bargaining as the main method for advancing workers' interests at workplace level. In so far as Korean workers depend on bargaining, we anticipate similar results; indeed, the same logic is likely to apply with greater force since Korean workers have had to be particularly reliant on their enterprise unions in the face of authoritarian management, a corporatist state, a quiescent official, legal union federation and, until December 1996, legal barriers to receiving support from union and other social groups outside the enterprise (Deyo 1989:138; Kim 1993:137; Shin and Wailes 1997).

\section{Data and methods}

The Korean industrial structure is dominated by about fifty Chaebol (conglomerate enterprise groups), which account for 40 per cent of employment and approximately 60 per cent of GNP. This sample consists of employees belonging to various different firms in one Chaebol, one of the three largest Chaebol in Korea. While each Chaebol has its own labour relations policies, there are two predominant types of strategy: paternalism, involving union avoidance (with Samsung being an exemplar), and pluralism, involving variable labour-management relations. Although our sample is drawn from pluralistic firms, this bias is less critical given an increasing tendency for governments to bestow legitimacy on unions and for union acceptance of the need for greater competitiveness.

The companies in our sample were engaged in a wide range of production and service activities including chemicals, electrical products, electronics (two companies), machinery (two companies), security services and fire insurance. All companies were large, employing more than 500 employees. Our sample is broadly representative of Korean union members. This is suggested by the following observations. The Korean industrial structure is dominated by about 40-50 Chaebol which are highly diversified in business terms and account for the majority of large enterprises. And it is in these enterprises that union members are concentrated, typically in large establishments (Kim 1993:142). Our sample reflects the significance of the large enterprise size and industrial diversity characteristic of Chaebol organization. ${ }^{\text {iv }}$ 
Questionnaires were mailed out to 15,000 employees in 1991, explaining the purposes of the survey. The 11,148 responses constitute a response rate of 75 per cent. After case-wise deletions for missing values, 5,293 cases remained for analysis. The employees were distributed among several different departments, with 57 per cent coming from production, 16 per cent from administration departments, 15 per cent from research and development and 9 per cent from sales and marketing. The sample includes blue and white-collar workers, with females comprising 23 per cent of the sample.

In order to maintain consistency with earlier research, we used a questionnaire similar to that reported in Jarley et al. (1990: 133), the only difference being that we omitted one question which had no discriminant validity in the Jarley et al. study. Employees were asked a total of ten questions regarding member satisfaction with various facets (i.e. dimensions) of union performance. In addition, one question asked how satisfied respondents were with the union in overall terms. The response categories in all cases were five-point Likert scales: 5 indicates 'very satisfied' while 1 indicates 'very dissatisfied' with any particular statement. The ten questions were then divided into different facets of union performance, consistent with Jarley et al. (1990). Each facet was measured by several questions (shown in the Appendix) and added to form a scale. The first facet comprising three items, measured satisfaction with union performance on economic issues such as wages, fringe benefits and job security. Scale reliability was 0.87 (Cronbach's alpha). The second facet sought to ascertain satisfaction with internal union relations, an aspect that includes processes of communication, representation and union leader effectiveness; six items comprised the scale, whose reliability was 0.85 . A third facet was measured by a single item asking about satisfaction with the union's efforts to improve the quality of members' work: 'Overall, how satisfied are you with the job being done by your union?'

Because Fiorito et al. (1988:301-2) found that members' satisfaction with their union is strongly influenced by their attitudes towards unionism in general, we sought to control for that attitude by asking a direct question about this. All else constant, we expected that higher scores on this measure would lead to higher scores on overall satisfaction with the union.

Our choice of data analysis procedures was dictated by two considerations. First, the dependent variable - overall union satisfaction - is not a continuous variable, but an ordered response variable; hence the use of the ordered probit estimation procedure rather than ordinary least squares regression (OLS) used in previous studies (e.g. Jarley et al. 1995). Second, OLS assumes that the relationship between the dependent variable and the independent variables is linear, an assumption that is not justified in this case; hence the need for probit estimation. Thus, we estimate the coefficients of the hypothesized determinants of overall union satisfaction, i.e. the different satisfaction facets, and the 
general union attitudes variable. Given that the data were collected from different companies belonging to different industries, we added company controls as well. Thus, our seven company controls (CU1CU7) are dummy variables that represent a chemical company, two machinery manufacturing firms, two electronics companies, one security services company and one insurance company. The omitted company was in the financial sector.

\section{Findings and interpretation}

Table 1 reports the means and standard deviations for all of our questions. The mean for the overall satisfaction question was $2.7($ s.d. $=0.93)$, suggesting that there is considerable disagreement regarding how satisfied members are with their unions. There is both a high degree of satisfaction and a certain amount of dissatisfaction. While the mean levels of satisfaction in this sample are similar to means levels reported in Swedish and American samples (Jarley et al. 1990), the variance is certainly greater here. The larger variance is probably due to the current ferment in the state of Korean unions generally as well as to other differences (e.g. differences in union leadership or democracy, or effectiveness in economic areas) across the eight unions that comprise this sample.

Interestingly, the means on all the items in Table 1, and in particular for the member-union relations items, or what we refer to as the INTERNAL RELATIONS items, tend to be higher than the means reported in the Jarley et al. study, where there was a greater level of dissatisfaction with the INTERNAL RELATIONS items. While we realize that there are several problems with the interpretation of mean differences across vastly different samples, it is important to note that the Swedish sample in the Jarley et al. study was composed of members of a professional union federation that encompassed a variety of occupations, though not in a single set of workplaces. In contrast, the members of the present sample belong to much smaller enterprise unions in just eight companies in a single Chaebol. Thus, they share a common context to a much greater extent than the workers in the Jarley et al. study. The contact between leaders and members was consequently lower for the Swedish sample in that study, and this factor may explain the lower means in that study. Even so, as indicated by our results reported below, Korean union members are not especially satisfied with this aspect.

It is also possible that the higher means in this sample relative to Jarley et al. could also be a function of the fact that Korean union members have been less exposed to surveys and therefore would tend to provide more socially desirable responses. This would have the effect of inflating the endorsement of union-member relations. Unfortunately, we cannot check this hypothesis, for we do not 
TABLE 1

Means and Standard Deviations of Individual Satisfaction Items

\begin{tabular}{|c|c|c|c|}
\hline Variable & Descriptor & Mean & Std dev. \\
\hline Getting better wages for your members & ECONOMIC & 2.83 & 1.09 \\
\hline Getting better fringe benefits for members & ECONOMIC & 3.07 & 1.03 \\
\hline Improving job security & ECONOMIC & 3.09 & 1.08 \\
\hline Listening to the concerns of members & $\begin{array}{l}\text { INTERNAL } \\
\text { RELATIONS }\end{array}$ & 2.86 & 0.98 \\
\hline Keeping members informed about union affairs & $\begin{array}{l}\text { INTERNAL } \\
\text { RELATIONS }\end{array}$ & 3.13 & 1.11 \\
\hline $\begin{array}{l}\text { Encouraging members to express opinions about the } \\
\text { collective contract }\end{array}$ & $\begin{array}{l}\text { INTERNAL } \\
\text { RELATIONS }\end{array}$ & 3.04 & 1.03 \\
\hline Giving members a say in how the union is run & $\begin{array}{l}\text { INTERNAL } \\
\text { RELATIONS }\end{array}$ & 2.88 & 1.04 \\
\hline Union officials' handling members' grievances & $\begin{array}{l}\text { INTERNAL } \\
\text { RELATIONS }\end{array}$ & 2.83 & 1.01 \\
\hline Availability of union officials when you need them & $\begin{array}{l}\text { INTERNAL } \\
\text { RELATIONS }\end{array}$ & 3.23 & 1.21 \\
\hline Getting management to improve the work itself & $\begin{array}{l}\text { QUALITY OF } \\
\text { WORK }\end{array}$ & 2.95 & 1.01 \\
\hline Overall satisfaction with union & & 2.70 & 0.93 \\
\hline
\end{tabular}

Note: ECONOMIC refers to items comprising extrinsic facets of employment; INTERNAL RELATIONS refers to items comprising relations between union members and leaders.

know the extent to which there were differences between the two samples of workers in exposure to member surveys. In any case, even if such inflation had occurred, it does not present a major problem for our analysis, as we are not interested in explaining why a certain level of satisfaction exists; rather, we are interested in accounting for factors that cause changes in union satisfaction.

Table 2 provides ordered probit estimates of the model. In overall terms, the model performs well. The normal statistic used here to evaluate such models is the chi-square, which in this case is both large $(3144.86)$ and significant $(p<0.001)$. This suggests that the model fits the data well. The pseudo Rsquare is also relatively high, given that the data are cross-sectional and are drawn from different samples.

As expected, overall union satisfaction is a function of the various facets of satisfaction measured here in that all the facets are significantly and positively related to overall union satisfaction. Yet, as the coefficients in Table 2 suggest, some facets are more important than others in determining a member's overall satisfaction with the union. Examining the $Z$ scores in Table 2 indicates the relative magnitude of the effects of different facets. The most important determinant of overall union 
satisfaction is the 'Internal union relations' facet, i.e. members' satisfaction with internal union relations.

TABLE 2

Ordered Probit Estimates of the Determinants of Overall Union Satisfaction

\begin{tabular}{|c|c|c|c|}
\hline Independent variables & Coefficient & Std errors & $z$ \\
\hline Economic issues & 0.270 & 0.283 & 9.540 \\
\hline Internal union relations & 0.911 & 0.311 & 29.252 \\
\hline Quality of work life & 0.058 & 0.020 & 2.823 \\
\hline General attitude towards unions & 0.068 & 0.024 & 2.742 \\
\hline \multicolumn{4}{|l|}{ Company controls } \\
\hline Company 1 & -0.198 & 0.042 & -4.613 \\
\hline Company 2 & -0.119 & 0.063 & -1.888 \\
\hline Company 3 & -0.154 & 0.072 & -2.113 \\
\hline Company 4 & 0.131 & 0.059 & 2.224 \\
\hline Company 5 & -0.022 & 0.068 & -0.035 \\
\hline Company 6 & 0.255 & 0.068 & 3.376 \\
\hline Company 7 & -0.284 & 0.100 & -2.845 \\
\hline Intercept 1 & 2.38 & 0.099 & \\
\hline Intercept 2 & 3.30 & 0.102 & \\
\hline Intercept 3 & 5.39 & 0.114 & \\
\hline Intercept 4 & 6.68 & 0.127 & \\
\hline Log likelihood & \multicolumn{3}{|c|}{-5160.325} \\
\hline Chi-square (11) & \multicolumn{3}{|c|}{3144.86} \\
\hline Pseudo $R$-square & \multicolumn{3}{|c|}{0.2335} \\
\hline$N$ & \multicolumn{2}{|c|}{5298} & \\
\hline
\end{tabular}

The $Z$ score for this variable is 29.25 , which is two and a half times greater than the $Z$ score for union performance on winning wages and benefit increases (the traditional economic benefits provided by unions to their members). Estimates (not shown) based on a probit analysis using the individual satisfaction items rather than the scale as the independent variables further indicate that 'availability of union officials when you need them', 'giving members a say in how the union is run', 'keeping the members informed about union affairs' and 'grievance handling' are the most important items influencing members' satisfaction with their union.

These results fly in the face of conventional wisdom, which holds that union members primarily care about the economic benefits provided by unions; rather, this result suggests the critical importance of fostering internal union democracy to increase members' satisfaction with their union. However, union performance on the economic issues was greater than the unions' efforts at improving the quality of work life in the firm. Thus, union members in this sample care more about the union's efforts at improving extrinsic aspects of their job (wages and benefits) over intrinsic aspects (the work itself). The Z-score for the 'Economic issues' variable (9.5) is two and a half times the size of the Z-score for the 'Quality of work life' variable. This result is quite similar to the results obtained by Jarley et al., except 
that the magnitude of the difference between the 'Economic issues' and 'Quality of work life' variables was not as great in their study.

Consistent with previous research, and controlling for the effect of members' actual experience with their union's performance, a member's general beliefs about unionism tends to positively impact satisfaction with their union. This suggests that people with a 'union mentality' (those who believe in the goals and values of unionism per se) are likely to evaluate their own union's efforts more positively than those who do not share those values.

These effects are not uniform, however, for the various different companies (unions) in our sample. Thus, controlling for the effects of the various satisfaction facets in determining overall union satisfaction, the results for the firm dummies suggest differences across the eight companies in the sample. The implication is that the characteristics of individual enterprise unions (other than the facets of internal relations and union performance on economic and quality of work life issues) significantly impact member satisfaction with unions. Absent more specific information on each of these unions, it is difficult to hypothesize just what these characteristics might be.

As hinted at earlier, the mean levels of union satisfaction (even if overstated) are still not very high (scores are typically 3 on a five-point scale), indicating considerable ambiguity on the part of members. Clearly, the context is important here, as Korean unions currently face tough times, and the transition to democracy and union fragmentation is causing a dent in the feeling of solidarity that was characteristic of the social movement unionism phase in Korea. In the area of member-union relationships as well, the ambiguity prevails, and is in line with the criticism that union leaders are quite out of touch with union members' views and are resisting calls for increased union democracy (Kim 1993:148).

One set of determinants of union satisfaction (in fact, all union attitudes) that we did not specifically include in our model consists of demographic variables. Many studies of union-related attitudes have examined the impact of several demographic variables such as age, gender, education and marital status on union attitudes. As Gallagher and Clark (1989) have suggested, there is considerable variation regarding the impact of these variables, resulting in no clear evidence of a causal connection. Our rationale for not including the demographic variables as predictors of union satisfaction rests on Kuruvilla et al. 's (1993:506) argument that there is no theory that links demographic variables to union attitudes. There is, for example, no reason why men and women should differ in their attitudes towards unions, or why there should be an attitudinal difference between older and younger people. 
Besides, in practical terms, the inclusion of these variables in the model did not change the results in any significant way.

In summary, the results from this sample of Korean workers are very similar to the results reported by Jarley et al. in their study of American and Swedish workers. The findings in both studies highlight the critical influence of member-union relations, in affecting member's satisfaction with the union. The results are best interpreted in terms of Gallagher and Strauss's observations that 'democratic procedures, perceived fairness, and officer responsiveness may be as important as collective gains' (1991: 168) in keeping members satisfied with unions. If anything, these results go a step further in suggesting that these factors are significantly more important than the traditional economic collective gains in structuring member satisfaction with their unions. It is also possible that both these aspects may be closely connected, for it can be argued that members' value their involvement in the democratic process, including representation by an effective leadership both in its own right and as a condition for obtaining higher wages and benefits. This, however, is a matter for further research.

More generally, our findings suggest that, quite apart from the value that Korean union members place on union democracy, their emphasis on internal union relations as a key source of satisfaction is consistent with the theory that decentralized collective bargaining depends on achievements that require union solidarity and leadership effectiveness.

\section{Conclusion}

Based on a survey of union members, we have shown that internal union relations - relations between rank-and-file members and local union leaders - is the most significant factor influencing union member satisfaction with their union. This contrasts with the instrumental view of unions which sees member satisfaction as dependent primarily on the economic benefits that unions deliver. This does not mean that unions should discount the latter in favour of promoting union democracy: rather, our findings suggest that it is a matter of unions giving higher priority to member-union relations. This is especially urgent in the context of current union weakness stemming from increasing unemployment occasioned by the financial crisis that began in 1997, and in the light of the phasing out of wages paid to enterprise union officials by employers, noted earlier. Consequently, there is an urgent need for more responsive organizational structures and communications processes, together with improved training of union leaders in time management and negotiations. Such reforms are especially pertinent to unions in a rapidly globalizing world, where market liberalization and deregulation are encouraging decentralized 
and largely informal collective bargaining. There is therefore a message here not only for Korean unions but also for unions in other industrializing East Asian countries.

Future research can contribute to improvements in internal union relations in a variety of ways. First, the theorizing and empirical examination of types of union representative structures and processes - e.g. workplace and enterprise union organizations and forms of communication and representation - may help union leaders to assess the impact of these factors on union member satisfaction. Union leaders might also learn from studies of changes in business and non-profit organizations that have used teams and new technology to create more flexible, participative structures. These considerations raise the question of what policy options are available to unions, to pursue either on their own or with the assistance of the state, to change their current form of internal union relations. A second theme is the relationship between member satisfaction with internal union relations and satisfaction with wages and conditions of employment. There is a need to theorize the relationships between union structures and employment relations strategies with the intention of discovering whether there are some strategies and institutional mechanisms that are able to optimize satisfaction with these aspects, thus attracting new members and satisfying current members simultaneously. Third, we need to know more about how the various facets of union satisfaction affect members' commitment to the union. In this respect, the concept of union satisfaction may need to be widened to include satisfaction with political activity, for the latter is important in many countries and is likely to become more salient in Korea, where the law now permits unions to support political parties.

\section{Appendix}

Items concerning union satisfaction included in the questionnaire are as follows:

How satisfied are you with the union's performance in:

Getting better wages for members?

ECONOMIC

Getting better fringe benefits? ECONOMIC

Improving job security? ECONOMIC

Listening to the concerns of members? INTERNAL RELATIONS

Keeping members informed about union affairs? INTERNAL RELATIONS

Encouraging members to express their opinions about the collective contract?

INTERNAL RELATIONS 
Giving members a say in how the union is run?

INTERNAL RELATIONS

Union officials' handling members' grievances?

INTERNAL RELATIONS

Availability of union officials when you need them?

INTERNAL RELATIONS

Getting management to improve the work itself?

QUALITY OF WORK

Overall, how satisfied are you with the union? (the 'Overall' question)

Final version accepted 26 February 1999.

\section{Acknowledgements}

Thanks to Professor Yeon-ang Jeong for providing us with the data and to Seung-Ho Kwon for further information. Hye-young Kang provided research assistance and George Strauss gave us valuable comments on an earlier draft.

\section{References}

Batstone, E., Boraston, I. and Frenkel, S. (1977). Shop Stewards in Action: The Organization of Workplace Conflict and Accommodation. Oxford: Blackwell.

Bem, D. J. (1972). 'Self-perception theory'. In L. Berkowitz (ed.). Advances in Experimental Social Psychology. New York: Academic Press.

Clegg, H. A. (1976). Trade Unionism under Collective Bargaining: A Theory basedon Comparisons of Six Countries. Oxford: Blackwell.

Deyo, F. (1989). Beneath the Miracle: Labor Subordination in the New Asian Industrialism. Berkeley: University of California Press.

Fiorito, J., Gallagher, D. G. and Fukami, C. V. (1988). 'Satisfaction with union representation'. Industrial and Labor Relations Review, 41: 294-307.

Fishbein, M. and Ajzen I. (1975). Belief, Attitude, Intention, and Behavior: An Introduction to Theory and Research. Reading Mass.: Addison Wesley.

Flanders, A. (1975). Management and Unions: The Theory and Reform of Industrial Relations. London: Faber \& Faber.

Gallagher, D. and Clark, P. F. (1989). 'Research on union commitment: implications for labor'. Labor Studies Journal, 14: $52-71$.

-and Strauss, G. (1991). 'Union membership attitudes and satisfaction'. In G.

Strauss, D. Gallagher and J. Fiorito (eds.). The State of the Union. Madison, Wis.: IRRA. 
Glick, M., Mirvis, P. and Harder, D. (1977). 'Union satisfaction and participation'. Industrial Relations, 16:145-51. Goldfield, M. (1987). The Decline of Organised Labor in the United States. Chicago: University of Chicago Press. Hammer, T. and Wazeter, D. L. (1993). 'Dimensions of local union effectiveness'. Industrial and Labor Relations Review, 46: 302-19.

International Labour Organization (ILO) (1997). Yearbook of Labour Statistics 1997. Geneva: International Labour Office.

-(1997). World Labour Report: Industrial Relations and Social Stability 1997-98. Geneva: International Labour Office.

Iversen, R. and Kuruvilla, S. (1996). 'Antecedents of union loyalty: the influence of individual dispositions and organizational context'. Journal of Organizational Behavior, 16: 557-82.

Jarley, P., Kuruvilla, S. and Casteei, D. (1990). 'Member-union relations and union satisfaction'. Industrial Relations, 29:128-34.

Kim, D.-O. (1997). 'Employment and industrial relations in East and Southeast Asia, focusing on Japan, South Korea, Taiwan, and Singapore'. Paper presented at the International Meeting on Employment and Labor Relations, Sao Paulo, Brazil, 7-8 April.

Kim, H. J. (1993). 'The Korean Union Movement in transition.' In S. Frenkel (ed.) Organized Labor in the Asia-Pacific Region: A Comparative Study of Trade Unionism in Nine Countries. Ithaca, NY: ILR Press. Korean Ministry of Labour, Survey Report on Conditions of the Labour Force, various issues. Korean Ministry of Labour, Monthly Labour Survey, various issues

Kuruvilla, S., Gallagher, D. G. and Wetzel, K. (1993). 'The development of members' attitudes toward their unions: Sweden and Canada'. Industrial and Labor Relations Review, 46: 499-514.

Lee, C. (1997). 'Korean trade union movement in the 1990s: survival or resurgence stage?' Paper presented at the Changing Approaches to Industrial Relations and Human Resources in the Asia- Pacific, including Australia, Korea and New Zealand Symposium, Griffith University, Brisbane, 29 January.

Leight, K. (1989). 'Unions, plants, jobs and workers: an analysis of union satisfaction and participation'. Sociological Quarterly, 43: 374-89.

Park, F. (1997). 'Industrial relations reform in Korea: 1996 labor law reform and its implications for industrial relations'. Paper presented at the Changing Approaches to Industrial Relations and Human Resources in the Asia-Pacific, including Australia, Korea and New Zealand Symposium, Griffith University, Brisbane, 29 January.

Park, S.-I. (1993).'The role of the state in industrial relations: the case of Korea'. Comparative Labor Law Journal, 14: 321-38.

Park, Y. and Lee, M. B. (1995). 'Economic development, globalization, and practices in industrial relations and human resource management in Korea'. In A. Verma, T. A. Kochan and R. Lansbury (eds.). Employment Relations in Growing Asian Economies. London: Routledge. 
Price, R. (1980). Masters, Unions and Men: Work Control in Building and the Rise of Labour, 1830-1914. Cambridge: Cambridge University Press.

Shin, J. S. and Wailes, N. (1997). 'The Korean Federation of Trade Unions: independent unionism in a newly industrializing country'. Paper presented at the Changing Approaches to Industrial Relations and Human Resources in the Asia-Pacific, including Australia, Korea and New Zealand Symposium, Griffith University, Brisbane, 29 January.

Strauss, G. (1991). 'Union democracy'. In G. Strauss, D. Gallagher and J. Fiorito (eds.). The State of the Union. Madison, Wis.: IRRA.

Sverke, M. and Kuruvilla, S. (1996). 'A new conceptualization of union commitment: development and test of an integrated theory'. Journal of Organizational Behavior, 16: 505-32.

Wilkinson, B. (1994). 'The Korea labour problem'. British Journal of Industrial

Relations, 32: 339-58.

\section{Notes}

\footnotetext{
i 1 . Working hours have tended to be relatively long in spite of legislation in 1989 to bring standard working hours down to 44 hours a week and subsequently to 40 hours through collective bargaining. In 1988 average working hours were 51.1 per week; by 1996 working hours had declined on average by nearly four hours a week (ILO 1997 : 684).

ii 2 . The external structure of unions is relevant to the issue of success in collective bargaining. We take this as a given, however, because union structure is a product of history and is difficult to change without substantial legal facilitation (see Clegg 1976: ch. 3).

iii 3. Labour market data referred to below are taken from Korean Ministry of Labour, Survey Report on Conditions of the Labour Force, various issues, and unpublished data.
}

iv 4 . One key source of bias in the sample could arise if the quality of labour management relationships differed by Chaebol, i.e. if each Chaebol is characterized by a particular style of labour-management relations that is present within every firm in the conglomerate. In addition, if bargaining in the conglomerate is conducted at enterprise group or industry level rather than at firm level, this would strengthen the case that a sample from one Chaebol is not sufficiently representative of workers from other Chaebol. This is not the case. Bargaining is focused at the enterprise level in Korea and there is variation between firms within any particular Chaebol. The quality of labourmanagement relationships is firm-specific rather than dependent on membership of a specific Chaebol. Our results support this proposition, for we find considerable variation in the way members evaluated their unions, although they all belong to the same Chaebol. 